\title{
Pengaruh Dukungan Organisasi Dan Kompensasi Terhadap Kinerja Awak Kapal Tunda Melalui Kepuasan Kerja Pada PT. Aman Bahari Kuala Tanjung
}

\author{
Dicky Arie Ananta Siregar \\ Universitas Muhammadiyah Sumatera Utara Medan, Indonesia
}

\section{Fajar Pasaribu}

Universitas Muhammadiyah Sumatera Utara Medan, Indonesia fajarpasaribu@umsu.ac.id

\begin{abstract}
The purpose of this study was to examine and analyze the effect of organizational support and compensation on performance through job satisfaction of tugboat crews at PT. Aman Bahari Kuala Tanjung directly or indirectly. The approach used in this research is a causal approach. The population in this study were all tugboat crews at PT. Aman Bahari Kuala Tanjung. The sample in this study using a saturated sample of 57 tugboat crew at PT. Aman Bahari Kuala Tanjung. Data collection techniques in this study used documentation, observation, and questionnaires. The data analysis technique in this study uses a quantitative approach using statistical analysis using the Auter Model Analysis test, Inner Model Analysis, and Hypothesis Testing. Data processing in this study uses the PLS (Partial Least Square) software program. The results of this study prove that directly organizational support, compensation and job satisfaction have a significant effect on performance and indirectly organizational support and compensation have a significant effect on performance through crew job satisfaction. tugs at PT. Aman Bahari Kuala Tanjung
\end{abstract}

Keywords Organizational Support, Compensation, Job Satisfaction, Performance

\section{PENDAhuluan}

Peningkatan jumlah perusahaan di Indonesia menuntut setiap perusahaan untuk menyesuaikan diri terhadap perkembangan yang ada agar dapat bersaing dan bertahan dengan baik dari waktu ke waktu. Dalam hal ini, sumber daya manusia merupakan faktor penting penentu kesuksesan perusahaan dalam mencapai tujuannya, karena berhasil atau tidaknya perusahaan dalam mencapai tujuan sangat tergantung pada kemampuan SDM atau karyawannya. Kemampuan karyawan dalam menjalankan tugas-tugasnya dapat dilihat melalui kinerja, sehingga kinerja karyawan menjadi hal yang sangat penting bagi keberhasilan perusahaan. (Hendro, 2018). Kinerja pada umumnya diartikan sebagai kesuksesan seseorang dalam melaksanakan suatu pekerjaan. Kinerja karyawan merupakan hasil kerja yang dicapai seseorang dalam melaksanakan tugas-tugas yang dibebankan kepadanya untuk mencapai target kerja. Karyawan dapat bekerja dengan baik bila memiliki kinerja yang tinggi sehingga dapat menghasilkan kerja yang baik. Kinerja karyawan merupakan salah satu faktor penentu keberhasilan instansi atau organisasi dalam mencapai tujuannya. Untuk itu kinerja dari para karyawan harus mendapat 
perhatian dari para pimpinan instansi, sebab menurunnya kinerja dari karyawan dapat mempengaruhi kinerja instansi secara keseluruhan (Permana, 2015). Kinerja suatu tampilan keadaan secara utuh atas perusahaan selama periode waktu tertentu, merupakan hasil atau prestasi yang dipengaruhi oleh kegiatan operasional perusahaan dalam memanfaatkan sumber-sumber daya yang dimiliki (Rivai, 2014). Kinerja (prestasi kerja) adalah hasil secara kualitas dan kuantitas yang dicapai oleh seorang pegawai dalam melaksanakan tugasnya sesuai dengan tanggung jawab yang diberikan kepadanya (Mangkunegara, 2014). Banyak faktor yang mempengaruhi produktivitas kerja seperti tingkat pendidikan, disiplin, sikap dan etika kerja, motivasi, giji dan kesehatan, tingkat penghasilan , jaminan sosial, lingkungan kerja, iklim kerja, teknologi, sarana produksi, manajemen, dan prestasi kerja akan meningkatkan kemampuan dalam bekerja serta diberi motivasi oleh perusahaan (E Sutrisno, 2010).

Dukungan organisasional merupakan faktor yang mempengaruhi kinerja. Persepsi dukungan organisasional adalah merupakan konsep utama dari teori dukungan organisasional. Persepsi dukungan organisasional sebagai keyakinan global karyawan mengenai sejauhmana organisasi peduli terhadap kesejahteraan mereka dan menghargai kontribusi mereka. (Putra, 2016). Dukungan organisasi dipandang sangat penting bagi perilaku pekerjanya. Organisasi memiliki kewajiban untuk mengembangkan suatu iklim yang mendukung orientasi konsumen. Dukungan organisasi dan manajemen akan meningkatkan motivasi perilaku orientasi pelanggan dari para pekerjanya dimana individu yang mempunyai nilai-nilai yang sama dengan organisasi, maka mereka akan mudah berinteraksi secara efisien dengan sistem nilai organisasi, mengurangi ketidakpastian, dan konflik serta meningkatkan kepuasan dan meningkatkan kinerja. (Metria, 2018).

Kompensasi adalah suatu faktor penting dan menjadi perhatian pada banyak organisasi dalam memperthankan dan menarik sumber daya manusia yang berkualitas. Sistem kompensasi yang baik berarti memberikan penghargaan-penghargaan yang layak dan adil sebagaimana kotribusi karyawan atas pekerjaanya. Pemberian kompensasi yang baik akan mendorong karyawan dalam bekerja dengan makin baik dan produktif (Lupiyoadi \& Hamdani, 2011). Kompensasi adalah suatu ilmu yang membahas tentang bagaimana mengelola, merencanakan, mengorganisasikan, mengatur dan mengawasai pemberian kompensasi atau balas jasa kepada SDM sehingga SDM dapat bekerja dengan totalitas yang tinggi dan mampu mendukung pencapaian tujuan organisasi (Khair, 2017). Selain itu kinerja karyawan dalam suatu perusahaan dipengaruhi oleh beberapa faktor yaitu peningkatan kepuasan kerja karyawan. Karena tingkat kepuasan akan dapat meningkatkan semangat kerja karyawan, jadi dapat disimpulkan bahwa hubungan antara karyawan dengan perusahaan menjadi hubungan timbal balik. Ketidakpuasan dan rendahnya tingkat kepuasan karyawan dapat menimbulkan gangguan dan hambatan serta ketidak lancaran suatu perusahaan juga semua proses yang ada didalamnya (Makaluas, 2017). Kepuasan kerja adalah suatu sikap karyawan terhadap pekerjaan yang berhubungan dengan situasi kerja, kerja sama antar karyawan, imbalan yang diterima dalam kerja, dan hal-hal yang menyangkut faktor fisik dan psikologis(E Sutrisno, 2010).

\section{LANDASAN TEORI \\ Kinerja}

Kinerja merupakan suatu hasil kerja yang dihasilkan oleh seorang karyawan diartikan untuk mencapai tujuan yang diharapkan. Selain itu kinerja seorang karyawan merupakan hal yang bersifat individual, karena setiap karyawan mempunyai tingkat 
kemampuan yang berbeda - beda dalam mengerjakan tugasnya. Pihak manajemen dapat mengukur karyawan atas hasil kerjanya berdasarkan kinerja dari masing - masing karyawan. Kinerja dan bukan merupakan hasil yang dapat dilihat pada saat itu juga. Pada dasarnya kinerja merupakan sesuatu hal yang bersifat individual, karena setiap karyawan memiliki tingkat kemampuan yang berbeda dalam mengerjakan tugasnya. Menurut (Mangkunegara, 2014) berpendapat bahwa kinerja karyawan adalah hasil kerja secara kualitas dan kuantitas yang dicapai oleh seseorang karyawan dalam melaksnakan tugasnya sesuai dengan tanggung jawab yang diberikan kepadanya. Menurut (Wibowo, 2010) menyatakan bahwa kinerja berasal darikata performance yang berarti hasil pekerjaan atau prestasi kerja. Namun perlu dipahami bahwa kinerja itu bukan sekedar hasil pekerjaan atau prestasi kerja, tetapi juga mencakup bagaimana proses pekerjaan itu berlangsung. Menurut (Nooralizad et al., 2011) "Kinerja sebagai sesuatu yang tampak, dimana individu relavan dengan tujuan organisasi.Kinerja yang baik merupakan salah satu sasaran organisasi dalam pencapaian produktivitas kerja yang tinggi.Tercapainya kinerja yang baik tidak terlepas dari kualitas sumber daya manusia yang baik pula.

Indikator kinerja merupakan sesuatu yang akan dihitung dan diukur. Adapun indikator kinerja (Mangkunegara, 2014)menyatakan yaitu :

1. Kualitas kerja

Kualitas kerja adalah mutu yang harus dihasilkan dalam pekerjaan.

2. Kuantitas kerja

Kuantitas kerja adalah jumlah yang harus diselesaikan dan dicapai dalam pekerjaan.

3. Dapat tidaknya diandalkan

Dapat tidaknya diandalkan merupakan apakah seseorang karyawan dapat mengikuti instruksi, memiliki inisiatif, hati-hati dan rajin dalam bekerja.

4. Sikap

Sikap yang dimiliki terhadap perusahaan, karyawan lain pekerjaan secara kerjasama.

Sedangkan menurut (Sutrisno, 2010) mengemukakan bahwa dimensi dan indikator kinerja dapat diukur yaitu sebagai berikut:

1. Kualitas Kerja

Kualitas kerja adalah seberapa baik seseorang karyawan mengerjakan apa yang seharusnya dikerjakan.

2. Kuantitas Kerja.

Kuantitas kerja adalah seberapa lama seseorang karyawan bekerja dalam satu harinya.

Kuantitas kerja ini dapat dilihat dari kecepatan kerja setiap karyawan itu masingmasing.

3. Tanggung Jawab.

Tanggung jawab terhadap pekerjaan adalah kesadaran akan kewajiban karyawan untuk melaksanankan pekerjaan yang diberikan perusahaan.

4. Kerjasama.

Kesediaan karyawan untuk berpartisipasi dengan karyawan atau pegawai lain secara vertikal dan horizontal baik didalam maupun diluar pekerjaan sehingga hasil pekerjaan semakin baik.

5. Inisiatif.

Inisiatif dari dalam diri anggota perusahaan untuk melakukan pekerjaan serta mengatasi masalah dalam pekerjaan tanpa menunggu perintah dari atasan atau menunjukan tanggung jawab dalam pekerjaan yang sudah menjadi kewajiban karyawan maupun pegawai. 


\section{Dukungan Organisasi}

Persepsi dukungan organisasi mengacu pada persepsi karyawan mengenai sejauh mana organisasi menilai kontribusi, memberi dukungan, dan peduli pada kesejahteraan mereka Menurut (Maryati, 2014) mendeskripsikan, Dukungan organisasi adalah kepercayaan pegawai bahwa organisasi peduli dan menilai setiap kontribusinya demi kesuksesan organisasi. Sedangkan menurut (Danish et al., 2013), dukungan organisasi merupakan ekspektasi pegawai bahwa organisasi menghargai kontribusi dan pekerjaan yang pegawai lakukan dengan sebaiknya. Selanjutnya menurut (Erdogan \& Enders, 2007), dukungan oganisasi merupakan derajat kepercayaan individu terhadap organisasi bahwa organisasi peduli kepadanya, menilai setiap masukan yang diberikan, dan menyediakan pertolongan dan bantuan untuknya. Dari beberapa uraian di atas, dapat disintesiskan bahwa dukungan organisasi adalah kepercayaan pegawai tentang seberapa jauh organisasi tempat dia bekerja menghargai kontribusi dan peduli akan kesejahteraannya.

Indikator dukungan organisasi menurut (Rhoades \& Eisenberg, 2008) adalah sebagai berikut:

1. Penghargaan; perusahaan memberikan penghargaan/reward atas pencapaian kerja karyawan.

2. Kondisi kerja; mengenai lingkungan tempat bekerja secara fisik maupun non-fisik.

3. Kesejahteraan karyawan; perusahaan peduli dengan kesejahteraan hidup karyawan

\section{Kompensasi}

Kompensasi merupakan bentuk balas jasa untuk karyawan yang diberikan kepada perusahaan. Dapat bersifat finansial maupun non-finansial pada periode yang tetap. Karyawan yang bekerja dalam sebuah organisasi pasti membutuhkan kompensasi atau imbalan yang cukup dan adil, malah kalau bisa cukup kompetitif di banding dengan organisasi atau perusahaan lain. Sistem kompensasi yang baik akan sangat mempengaruhi semangat kerja dan produktivitas dari seseorang. Suatu sistem kompensasi yang baik perlu didukung oleh metode secara rasional yang dapat menciptakan seseorang digaji atau diberi kompensasi sesuai tuntunan pekerjaannya. Menurut (Larasati, 2018) kompensasi adalah segala sesuatu imbalan yang diterima karyawan dalam bentuk finansial maupun non finansial baik secara langsung maupun tidak langsung atas kewajiban yang telah diberikan oleh perusahaan dan karyawan menerima jasa secara adil.

Menurut (E Sutrisno, 2010) kompensasi merupakan salah satu fungsi yang penting dalam manajemen sumber daya manusia (MSDM). Karena kompensasi merupakan salah satu aspek yang paling sensitif dalam hubungan kerja. Menurut (Susanto, 2017) kompensasi seluruh bentuk imbalan baik berupa finansial maupun non finansial seperti upah, gaji, tunjangan, bonus, uang makan, uang lembur jaminan kesehatan dan insentif yang diberikan kepada pegawai sebagai imbalan atau balas jasa dalam melakukan tugas keorganisasian. Berdasarkan pengertian Kompensasi dari beberapa pendapat diatas, kompensasi merupakan segala sesuatu yang diterima dapat berupa fisik maupun non fisik dan harus dihitung dan diberikan kepada seseorang yang umumnya merupakan objek yang dikecualikan dari pajak pendapatan.

Indikator-indikator kompensasi menurut (Hasibuan, 2010) mengemukakan, secara umum ada beberapa indikator kompensasi, yaitu:

1. Gaji/upah,

2. Asuransi,

3. Tunjangan, 
4. Premi.

Sedangkan menurut (Mangkunegara, 2014) indikator kompensasi yaitu:

1. Tingkat bayaran,

2. Struktur pembayaran,

3. Penentuan bayaran individu,

4. Metode pembayaran, dan

5. Kontrol pembayaran.

Berdasarkan beberapa teori indikator kompensasi di atas dapat disimpulkan bahawa indikator kompensasi adalah gaji, upah, insentif, fasilitas, asuransi, tunjangan, premi, tingkat bayaran, struktur bayaran, penentuan bayaran individu, metode pembayaran, dan kontrol pembayaran.

\section{Kepuasan Kerja}

Kepuasan kerja merupaakan salah satu elemen yang cukup penting dalam salah satu organisasi. Hal ini disebabkan kepuasan kerja dapat mempengaruhi perilaku kerja seperti malas, rajin, produktif, dan lain-lain, atau mempunyai hubungan dengan beberapa jenis perilaku yang sangat penting dalam organisasi. Menurut (E Sutrisno, 2010) "kepuasan kerja karyawan merupakan masalah penting yang diperhatikan dalam hubungannya dengan produktivitas kerja karyawan dan ketidakpuasan sering dikaitkan dengan tingkat tuntutan dan keluhan pekerjaan yang tinggi. Pekerja dengan tingkat ketidakpuasan yang tinggi lebih mungkin untuk melakukan sabotase dan agresi yang pasif".

Menurut (Yulianita, 2017) "kepuasan kerja merupakan salah satu elemen yang cukup penting dalam salah satu organisasi. Hal ini disebabkan kepuasan kerja dapat mempengaruhi perilaku kerja seperti malas, rajin, produktif, dan lain-lain, atau mempunyai hubungan dengan beberapa jenis perilaku yang sangat penting dalam organisasi". Munurut (Handoko, 2013) "kepuasan kerja adalah keadaan emosional yang menyenangkan atau tidak menyenangkan dengan mana para karyawan memandang pekerjaan mereka". Sedangkan Menurut (Siagian, 2014) kepuasan kerja merupakan suatu cara pandang seseorang baik yang bersifat positif maupun yang bersifat negatif tentang pekerjaannya.

Tolak ukur kepuasan kerja yang mutlak sulit untuk dicari karena setiap individu karyawan berbeda standar kepuasannya. Adapun indikator-indikator kepuasan kerja menurut (Hasibuan, 2010) antara lain:

1. Kesetiaan

Penilai mengukur kesetiaan karyawan terhadap pekerjaannya, jabatannya, dan organisasi. Kesetiaan ini dicerminkan oleh kesediaan karyawan menjaga dan membela organisasi didalam maupun diluar pekerjaannya dari rongrongan orang yang tidak bertanggung jawab.

2. Kemampuan

Penilai menilai hasil kerja baik kualitas maupun kuantitas yang dapat dihasilkan karyawan tersebut dari uraian pekerjaannya.

3. Kejujuran

Penilai menilai kejujuran dalam melaksanakan tugas-tugasnya memenuhi perjanjian baik bagi dirinya sendiri maupun terhadap orang lain.

4. Kreatifitas

Penilai menilai kemampuan karyawan dalam mengembangkan kreativitasnya untuk menyelesaikan pekerjaannya, sehingga akan dapat bekerja lebih baik. 


\section{Kepemimpinan}

Penilai menilai kemampuan untuk memimpin, mempunyai pribadi yang kuat, dihormati, berwibawa dan dapat memotivasi orang lain atau bawahannya untuk bekerja secara efektif.

\section{Tingkat Gaji}

Penilai menilai jumlah gaji yang diberikan perusahaan dan diterima karyawan harus sesuai dengan apa yang karyawan berikan terhadap perusahaan agar mereka merasa puas.

\section{Pengembangan Hipotesis}

\section{Hubungan Kompensasi Terhadap Kinerja}

Kompensasi merupakan bentuk balas jasa untuk karyawan yang diberikan kepada perusahaan. Dapat bersifat finansial maupun non-finansial pada periode yang tetap. Karyawan yang bekerja dalam sebuah organisasi pasti membutuhkan kompensasi atau imbalan yang cukup dan adil, malah kalau bisa cukup kompetitif di banding dengan organisasi atau perusahaan lain. Sistem kompensasi yang baik akan sangat mempengaruhi semangat kerja dan produktivitas dari seseorang. Suatu sistem kompensasi yang baik perlu didukung oleh metode secara rasional yang dapat menciptakan seseorang digaji atau diberi kompensasi sesuai tuntunan pekerjaannya.

H1 : kompensasi berpengaruh terhadap kinerja.

\section{Hubungan Kepuasan Kerja Terhadap Kinerja}

Kepuasan kerja merupakan hal yang bersifat individual dan tergantung pada persepsi seseorang tentang apa yang dirasakannya mengenai pekerjaan. Menurut (Hasibuan, 2010) kepuasan kerja adalah sikap emosional yang menyenangi dan mencintai pekerjaannya. Sikap ini dicerminkan oleh moral kerja, kedisiplinan, dan prestasi kerja. $\mathrm{H} 2$ : kepuasan kerja berpengaruh terhadap kinerja.

\section{Hubungan Dukungan Organisasi Terhadap Kepuasan Kerja}

Dukungan organisasi mengusulkan bahwa karyawan membentuk persepsi umum mengenai sejauh mana organisasi menyediakan sumber daya yang memadai dan menghargai mereka sebagai individu, termasuk kemungkinan bahwa organisasi akan menghargai kinerja mereka dan membantu mereka selama sulit (Cullen et al., 2013).

H3 : Dukungan organisasi berpengaruh terhadap kepuasan kerja

\section{Hubungan Kompenasi Terhadap Kepuasan Kerja}

Kompensasi kepada karyawan akan memberikan kepuasan kerja tersendiri untuk karyawan, apabila seorang karyawan mendapatkan kompensasi yang pantas atas apa yang sudah dikerjakan pada perusahaan maka karyawan tersebut juga akan mendapatkan kepuasan kerja yang baik (Hasibuan, 2010).

H4 : kompensasi berpengaruh terhadap kepuasan kerja.

\section{Hubungan Kompensasi Terhadap Kinerja Melalui Kepuasan Kerja}

Kompensasi kepada karyawan akan memberikan kepuasan kerja tersendiri untuk karyawan, apabila seorang karyawan mendapatkan kompensasi yang pantas atas apa yang sudah dikerjakan pada perusahaan maka karyawan tersebut juga akan mendapatkan kepuasan kerja yang baik sehingga semangat kerja keryawan tersebut akan semakin tinggi dan pada akhirnya kinerja karyawan akan semakin tinggi.

H5 :Kompensasi berpengaruh terhadap kinerja kepuasan kerja 


\section{METODOLOGI PENELITIAN}

Penelitian ini dilaksanakan mulai bulan Januari 2021 sampai dengan Juni 2021, Penelitian ini termasuk dalam kategori penelitian kausal dengan menggunakan pendekatan kuantitatif. Penelitian ini dilaksanakan di kantor PT. Aman Bahari Kuala Tanjung Jalan Pelabuhan Kuala Tanjung, Sei Suka, Kwala Tj., Kec. Sei Suka, Kabupaten Batu Bara, Sumatera Utara. Populasi dalam penelitian ini adalah seluruh awak kapal tunda pada PT. Aman Bahari Kuala Tanjung yang berjumlah 57 orang, Adapun Untuk penentuan jumlah/ukuran sampel dalam penelitian ini dengan metode sampel jenuh dimana semua anggota populasi dijadikan sampel yaitu sebanyak 57 orang.

\section{HASIL DAN PEMBAHASAN \\ Analisis Inner Model}

$R$-square adalah ukuran proporsi variasi nilai yang dipengaruhi (endogen) yang dapat dijelaskan oleh variabel yang mempengaruhinya (eksogen) ini berguna untuk memprediksi apakah model adalah baik/buruk. Hasil $r$-square untuk variabel laten endogen sebesar 0,75 mengindikasikan bahwa model tersebut adalah substansial (baik); 0,50 mengindikasikan bahwa model tersebut adalah moderat (sedang) dan 0,25 mengindikasikan bahwa model tersebut adalah lemah (buruk) (Juliandi, 2018). Berdasarkan pengolahan data yang telah dilakukan dengan menggunakan program smartPLS 3.0, diperoleh nilai $R$-Square yang dapat dilihat pada gambar dan tabel berikut:

Tabel 1. Hasil Uji R-Square

\begin{tabular}{|l|ll|l|}
\hline & R Square & R Square Adjusted & \\
\hline Y & & 0.963 & \\
\hline
\end{tabular}

\section{Sumber : PLS 3.00}

Dari tabel 1 di atas diketahui bahwa pengaruh X1, X2 dan $\mathrm{Z}$ terhadap $\mathrm{Y}$ dengan nilai r-square 0,963 mengindikasikan bahwa variasi nilai Y mampu dijelaskan oleh variasi nilai $\mathrm{X}$ dan $\mathrm{Z}$ sebesar $96,3 \%$ atau dengan kata lain bahwa model tersebut adalah substansial (baik), dan 3,7\% dipengaruhi oleh variabel lain.

\section{Pengujian Hipotesis}

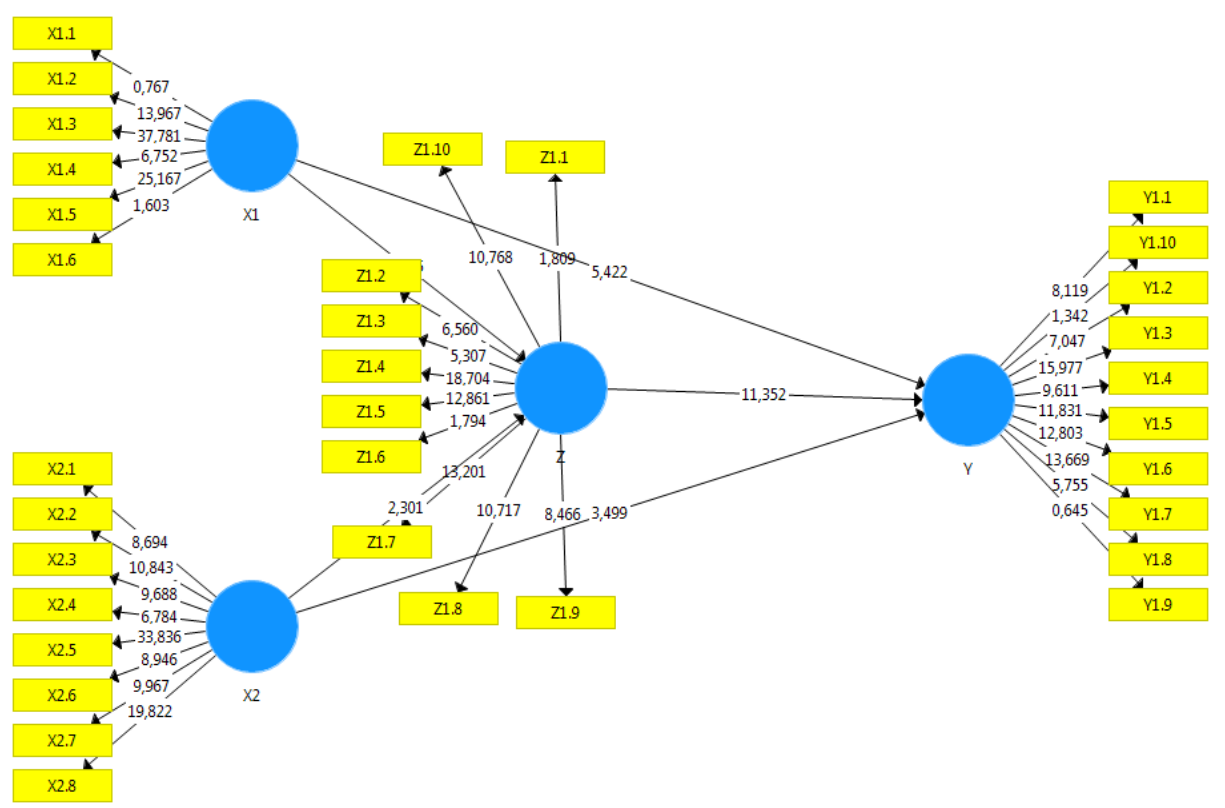




\section{Gambar 1. Path Coefficient}

\section{Pengujian Hipotesis Pengaruh Langsung}

Hasil uji hipotesis pengaruh langsung dapat dilihat pada tabel path coefficient berikut ini:

Tabel 2. Path Coefficient

\begin{tabular}{|l|r|r|r|r|r|}
\hline & \multicolumn{1}{|l|}{$\begin{array}{l}\text { Original } \\
\text { Sample (0) }\end{array}$} & $\begin{array}{l}\text { Sample } \\
\text { Mean (M) }\end{array}$ & $\begin{array}{l}\text { Standard } \\
\text { Error } \\
\text { (STERR) }\end{array}$ & $\begin{array}{l}\text { T Statistics } \\
\text { (|O/STERR|) }\end{array}$ & P Values \\
\hline $\mathbf{X 1 ~}>\mathbf{Y}$ & 0,331 & 0,320 & 0,061 & 5,422 & $\mathbf{0 . 0 0 0}$ \\
\hline $\mathbf{X 1 ~}>\mathbf{Z}$ & 0,476 & 0,476 & 0,149 & 3,185 & $\mathbf{0 . 0 0 2}$ \\
\hline $\mathbf{X} \mathbf{2}>\mathbf{Y}$ & 0,189 & 0,198 & 0,054 & 3,499 & $\mathbf{0 . 0 0 1}$ \\
\hline $\mathbf{X 2 ~}>\mathbf{Z}$ & 0,371 & 0,368 & 0,161 & 2,301 & $\mathbf{0 . 0 2 2}$ \\
\hline $\mathbf{Z}>\mathbf{Y}$ & 0,535 & 0,540 & 0,047 & 11,352 & $\mathbf{0 . 0 0 0}$ \\
\hline
\end{tabular}

\section{Sumber : PLS 3.00}

Berdasarkan Tabel 6 di atas, dapat dinyatakan bahwa pengujian hipotesis adalah sebagai berikut:

1. Pengaruh dukungan organisasi terhadap kinerja mempunyai koefisien jalur sebesar 0,331 . Ini menunjukkan bahwa jika semakin baik dukungan oganisasi, maka semakin tinggi kinerja pada awak kapal tunda pada PT. Aman Bahari Kuala Tanjung. Pengaruh tersebut mempunyai nilai probabilitas (p-values) sebesar $0,000<0,05$, berarti dukungan organisasi berpengaruh signifikan terhadap kinerja awak kapal tunda pada PT. Aman Bahari Kuala Tanjung.

2. Pengaruh dukungan organisasi terhadap kepuasan kerja mempunyai koefisien jalur sebesar 0,476. Ini menunjukkan bahwa jika semakin baik dukungan organisasi, maka semakin tinggi kepuasan kerja pada awak kapal tunda pada PT. Aman Bahari Kuala Tanjung. Pengaruh tersebut mempunyai nilai probabilitas (p-values) sebesar 0,002 < 0,05 , berarti dukungan organisasi berpengaruh signifikan terhadap kepuasan kerja awak kapal tunda pada PT. Aman Bahari Kuala Tanjung.

3. Pengaruh kompensasi terhadap kinerja mempunyai koefisien jalur sebesar -0,189. Ini menunjukkan bahwa jika semakin baik kompensasi, maka semakin tinggi kinerja pada awak kapal tunda pada PT. Aman Bahari Kuala Tanjung. Pengaruh tersebut mempunyai nilai probabilitas ( $\mathrm{p}$-values) sebesar 0,001<0,05, berarti kompensasi berpengaruh signifikan terhadap kinerja awak kapal tunda pada PT. Aman Bahari Kuala Tanjung.

4. Pengaruh kompensasi terhadap kepuasan kerja mempunyai koefisien jalur sebesar 0,371. Ini menunjukkan bahwa jika semakin baik kompensasi, maka semakin tinggi kepuasan kerja pada awak kapal tunda pada PT. Aman Bahari Kuala Tanjung. Pengaruh tersebut mempunyai nilai probabilitas (p-values) sebesar 0,022 $<0,05$, berarti kompensasi berpengaruh signifikan terhadap kepuasan kerja awak kapal tunda pada PT. Aman Bahari Kuala Tanjung.

5. Pengaruh kepuasan kerja terhadap kinerja mempunyai koefisien jalur sebesar -0,535. Ini menunjukkan bahwa jika semakin baik kepuasan kerja, maka semakin tinggi kinerja pada awak kapal tunda pada PT. Aman Bahari Kuala Tanjung. Pengaruh tersebut mempunyai nilai probabilitas (p-values) sebesar $0,000<0,05$, berarti kepuasan kerja berpengaruh signifikan terhadap kinerja awak kapal tunda pada PT. Aman Bahari Kuala Tanjung.

\section{Pengujian Secara Tidak Langsung}


Adapun pengaruh tidak langsung diantara variabel bebas dan variabel terikat pada penelitian ini dapat dikemukakan adalah sebagai berikut :

Tabel 3. Specific Indirect Effects

\begin{tabular}{|c|c|c|c|c|c|}
\hline & $\begin{array}{l}\text { Original } \\
\text { Sample (0) }\end{array}$ & $\begin{array}{l}\text { Sample } \\
\text { Mean } \\
\text { (M) }\end{array}$ & $\begin{array}{l}\text { Standard } \\
\text { Deviation } \\
\text { (STDEV) }\end{array}$ & $\begin{array}{l}\text { T Statistics } \\
\text { (|O/STDEV|) }\end{array}$ & $\begin{array}{l}\mathbf{P} \\
\text { Values }\end{array}$ \\
\hline X1 -> & 0.254 & 0.256 & 0.081 & 3,127 & 0.002 \\
\hline$X 2->Z$-> Y & 0.198 & 0.198 & 0.090 & 2,196 & 0.029 \\
\hline
\end{tabular}

\section{Sumber : PLS 3.00}

Berdasarkan Tabel 7 di atas, dapat dinyatakan bahwa pengujian hipotesis adalah sebagai berikut:

1. Pengaruh dukungan organisasi terhadap kinerja melalui kepuasan kerja mempunyai koefisien jalur sebesar 0,254 . Pengaruh tersebut mempunyai nilai probabilitas ( $p$ values) sebesar $0,002<0,05$, berarti dapat disimpulkan bahwa dukungan organisasi berpengaruh signifikan terhadap kinerja melalui kepuasan kerja awak kapal tunda pada PT. Aman Bahari Kuala Tanjung.

2. Pengaruh kompenasasi terhadap kinerja melalui kepuasan kerja mempunyai koefisien jalur sebesar 0,198 . Pengaruh tersebut mempunyai nilai probabilitas ( $\mathrm{p}$-values) sebesar $0,029<0,05$, berarti dapat disimpulkan bahwa kompensasi berpengaruh signifikan terhadap kinerja melalui kepuasan kerja awak kapal tunda pada PT. Aman Bahari Kuala Tanjung.

\section{PEMBAHASAN}

\section{Pengaruh Dukungan Organisasi Terhadap Kinerja}

Dari hasil analisis pengujian hipotesis diketahui bahwa dukungan organisasi berpengaruh signifikan terhadap kinerja yang dinilai dengan koefisien jalur sebesar 0,331 . Nilai probabilitas yang didapatkan adalah sebesar $0,000<0,05$, dengan nilai thitung sebesar 5,422, dan nilai $t_{\text {tabel }} 1.96$, dengan demikian $t_{\text {hitung }}$ lebih besar dari $t_{\text {tabel }}$ $(5,442>1.96)$ sehingga $\mathrm{H} 0$ ditolak (Ha diterima). Hal ini berarti dukungan organisasi berpengaruh signifikan terhadap kinerja awak kapal tunda pada PT. Aman Bahari Kuala Tanjung. Hal ini menunjukkan bahwa dengan semakin baiknya dukungan yang diberikan perusahaan kepada awak kapal tunda maka kinerja awak kapal akan semakin baik, dimana awak kapal akan berusahaan untuk bekerja lebih baik sehingga kinerja akan semakin tinggi.

Dukungan organisasi sangat berperan dalam menentukan kinerja anggota, dalam penelitiannya juga dijelaskan bahwa dukungan organisasi berhubungan dengan prestasi kerja, dimana penghargaan oleh organisasi dianggap memberikan keuntungan bagi anggota, seperti kenyamanan kerja karena diterima dan diakui, memperoleh gaji dan promosi, memperoleh informasi secara mudah, serta beberapa hal lain yang dibutuhkan anggota untuk dapat menjalankan pekerjaannya secara efektif. Persepsi dukungan organisasi mengacu pada persepsi karyawan mengenai sejauh mana organisasi menilai kontribusi, memberi dukungan, dan peduli pada kesejahteraan mereka. Menurut (Mary, 2012) mendeskripsikan, Dukungan organisasi adalah kepercayaan pegawai bahwa organisasi peduli dan menilai setiap kontribusinya demi kesuksesan organisasi.

. Hasil penelitian ini sejalan dengan hasil penelitian terdahulu yang dilakukan oleh (Riantoko et al., 2017), (Jufrizen et al., 2021) dan (Kadir et al., 2016) menyimpulkan bahwa dukungan organisasi berpengaruh terhadap kinerja 


\section{Pengaruh Kompensasi Terhadap Kinerja}

Dari hasil analisis pengujian hipotesis diketahui bahwa kompensasi berpengaruh signifikan terhadap kinerja yang dinilai dengan koefisien jalur sebesar 0,189. Nilai probabilitas yang didapatkan adalah sebesar $0,001<0,05$, dengan nilai thitung sebesar 3,499 , dan nilai tabel 1.96 , dengan demikian $t_{\text {hitung }}$ lebih besar dari $t_{\text {tabel }}(3,499>1.96)$ sehingga $\mathrm{H0}$ ditolak (Ha diterima). Hal ini berarti kompensasi berpengaruh signifikan terhadap kinerja awak kapal tunda pada PT. Aman Bahari Kuala Tanjung.

Kompensasi merupakan bentuk balas jasa untuk karyawan yang diberikan kepada perusahaan. Dapat bersifat finansial maupun non-finansial pada periode yang tetap. Karyawan yang bekerja dalam sebuah organisasi pasti membutuhkan kompensasi atau imbalan yang cukup dan adil, malah kalau bisa cukup kompetitif di banding dengan organisasi atau perusahaan lain. Sistem kompensasi yang baik akan sangat mempengaruhi semangat kerja dan produktivitas dari seseorang. Suatu sistem kompensasi yang baik perlu didukung oleh metode secara rasional yang dapat menciptakan seseorang digaji atau diberi kompensasi sesuai tuntunan pekerjaannya.

Dengan adanya kompensasi yang baik dalam perusahaan akan membawa dampak yang positif untuk perusahaan. Apabila karyawan mendapat kompensasi yang sesuai dengan apa yang telah dilakukan dalam perusahaan, maka karyawan akan cenderung melakukan yang terbaik untuk perusahaan. Sehingga, karyawan akan berusaha mempertahankan dan bahkan meningkatkan kinerjanya dalam perusahaan. Namun, apabila karyawan merasa kompensasi yang diberikan perusahaan tidak sesuai dengan kontribusi yang telah dilakukan untuk perusahaan maka karyawan akan cenderung kurang maksimal dalam melakukan tugas dan tanggung jawabnya untuk perusahaan. Hasil penelitian ini sejalan dengan hasil penelitian terdahulu yang dilakukan oleh (Pratama, 2015), (Jufrizen, 2018), (Jufrizen, 2016), (Jufrizen, 2017), (Usman et al., 2021), (Jufrizen et al., 2017) dan (Arif et al., 2019) menyimpulkan bahwa kompensasi berpengaruh terhadap kinerja.

\section{Pengaruh Kepuasan Kerja Terhadap Kinerja}

Dari hasil analisis pengujian hipotesis diketahui bahwa kepuasan kerja berpengaruh signifikan terhadap kinerja yang dinilai dengan koefisien jalur sebesar 0,535 . Nilai probabilitas yang didapatkan adalah sebesar $0,000<0,05$, dengan nilai thitung sebesar 11,352, dan nilai tabel 1.96, dengan demikian $t_{\text {hitung }}$ lebih besar dari $t_{\text {tabel }}$ (11,352>1.96) sehingga H0 ditolak (Ha diterima). Hal ini berarti kepuasan kerja berpengaruh signifikan terhadap kinerja awak kapal tunda pada PT. Aman Bahari Kuala Tanjung.

Ketika karyawan merasa sangat puas dengan pekerjaannya, gaji, rekan kerja dll, maka mereka akan melakukan kinerja dengan optimal. Ketika semua aspek kepuasan kerja yang berkaitan dengan karyawan dapat terpenuhi oleh perusahaan, maka karyawan akan melakukan optimalisasi kerja untuk perusahaan. Kepuasan kerja merupakan hal yang bersifat individual dan tergantung pada persepsi seseorang tentang apa yang dirasakannya mengenai pekerjaan. Menurut (Hasibuan, 2010) kepuasan kerja adalah sikap emosional yang menyenangi dan mencintai pekerjaannya. Sikap ini dicerminkan oleh moral kerja, kedisiplinan, dan prestasi kerja.

Hasil penelitian ini sejaalan dengan hasil penelitian terdahulu yang dilakukan oleh (Makaluas \& Sumampouw, 2017), (Adhan et al., 2020), (Syahputra \& Jufrizen, 2019) dan (Zahra \& Hidayat, 2017) menyimpulkan bahwa kepuasan kerja berpengaruh terhadap kinerja 


\section{Pengaruh Dukungan Organisasi Terhadap Kepuasan Kerja}

Dari hasil analisis pengujian hipotesis diketahui bahwa dukungan organisasi berpengaruh signifikan terhadap kepuasan kerja yang dinilai dengan koefisien jalur sebesar 0,476. Nilai probabilitas yang didapatkan adalah sebesar $0,002<0,05$, dengan nilai thitung sebesar 3,185 , dan nilai $t_{\text {tabel }} 1.96$, dengan demikian $t_{\text {hitung }}$ lebih besar dari $t_{\text {tabel }}(3,185>1.96)$ sehingga $\mathrm{H} 0$ ditolak (Ha diterima). Hal ini berarti dukungan organisasi berpengaruh signifikan terhadap kepuasan kerja awak kapal tunda pada PT. Aman Bahari Kuala Tanjung.

Persepsi dukungan organisasi mengacu pada persepsi karyawan mengenai sejauh mana organisasi menilai kontribusi, memberi dukungan, dan peduli pada kesejahteraan mereka. Menurut (Erdogan \& Enders, 2007), dukungan oganisasi merupakan derajat kepercayaan individu terhadap organisasi bahwa organisasi peduli kepadanya, menilai setiap masukan yang diberikan, dan menyediakan pertolongan dan bantuan untuknya.

Dukungan organisasi mengusulkan bahwa karyawan membentuk persepsi umum mengenai sejauh mana organisasi menyediakan sumber daya yang memadai dan menghargai mereka sebagai individu, termasuk kemungkinan bahwa organisasi akan menghargai kinerja mereka dan membantu mereka selama sulit (Cullen et al., 2013). Hasil penelitian ini sejalan dengan hasil penelitian terdahulu yang dilakukan oleh (Dewi et al., 2018) menyimpulkan bahwa dukungan organisasi berpengaruh terhadap kepuasan kerja.

\section{Pengaruh Kompensasi Terhadap Kepuasan Kerja}

Dari hasil analisis pengujian hipotesis diketahui bahwa kompensasi berpengaruh signifikan terhadap kepuasan kerja yang dinilai dengan koefisien jalur sebesar 0,371. Nilai probabilitas yang didapatkan adalah sebesar $0,022<0,05$, dengan nilai thitung sebesar 2,301 , dan nilai tabel 1.96 , dengan demikian $t_{\text {hitung }}$ lebih besar dari $t_{\text {tabel }}(2,301>1.96)$ sehingga H0 ditolak (Ha diterima). Hal ini berarti kompensasi berpengaruh signifikan terhadap kepuasan kerja awak kapal tunda pada PT. Aman Bahari Kuala Tanjung.

Karyawan yang bekerja dalam sebuah organisasi pasti membutuhkan kompensasi atau imbalan yang cukup dan adil, malah kalau bisa cukup kompetitif di banding dengan organisasi atau perusahaan lain. Sistem kompensasi yang baik akan sangat mempengaruhi semangat kerja dan produktivitas dari seseorang. Suatu sistem kompensasi yang baik perlu didukung oleh metode secara rasional yang dapat menciptakan seseorang digaji atau diberi kompensasi sesuai tuntunan pekerjaannya. Menurut (Larasati, 2018) kompensasi adalah segala sesuatu imbalan yang diterima karyawan dalam bentuk finansial maupun non finansial baik secara langsung maupun tidak langsung atas kewajiban yang telah diberikan oleh perusahaan dan karyawan menerima jasa secara adil.

Kompensasi kepada karyawan akan memberikan kepuasan kerja tersendiri untuk karyawan, apabila seorang karyawan mendapatkan kompensasi yang pantas atas apa yang sudah dikerjakan pada perusahaan maka karyawan tersebut juga akan mendapatkan kepuasan kerja yang baik (Hasibuan, 2010). Hasil penelitian ini sejalan dengan hasil penelitian terdahulu yang dilakukan oleh (Rahayu \& Riana, 2017) menyimpulkan bahwa kompensasi berpengaruh terhadap kepuasan kerja.

\section{Pengaruh Dukungan Organisas Terhadap Kinerja Melalui Kepuasan Kerja}

Dari hasil analisis pengujian hipotesis diketahui bahwa dukungan organisasi berpengaruh signifikan terhadap kinerja melalui kepuasan kerja yang dinilai dengan koefisien jalur sebesar 0,254. Nilai probabilitas yang didapatkan adalah sebesar 0,002 < 
0,05 , dengan nilai thitung sebesar 3,127, dan nilai tabel 1.96 , dengan demikian $t_{\text {hitung }}$ lebih besar dari $t_{\text {tabel }}(3,127>1.96)$ sehingga $\mathrm{H} 0$ ditolak (Ha diterima). Hal ini berarti dukungan organisasi berpengaruh signifikan terhadap kinerja melalui kepuasan kerja awak kapal tunda pada PT. Aman Bahari Kuala Tanjung.

Karyawan yang merasakan dukungan organisasi akan bisa bekerja dengan baik karena fasilitas serta kontribusi perusahaan yang membuat karyawan merasa nyaman dan aman memicu semangat kerja karyawan bertambah dan membuat karyawan bertahan pada perusahaan tersebut dalam jangka waktu yang lama. Hal ini menunjukkan bahwa semakin tinggi dukungan organisasi yang terjadi di perusahaan maka semakin tinggi juga kepuasan kerja pada karyawan sehingga karyawan akan terus giat dalam mengerjakan pekerjaanya dan pada akhirnya kienrja karyawan tersebut akan semakin meningkat.

\section{Pengaruh Kompensasi Terhadap Kinerja Melalui Kepuasan Kerja}

Dari hasil analisis pengujian hipotesis diketahui bahwa kompensasi berpengaruh signifikan terhadap kinerja melalui kepuasan kerja yang dinilai dengan koefisien jalur sebesar 0,198 Nilai probabilitas yang didapatkan adalah sebesar 0,029<0,05, dengan nilai thitung sebesar 2,196, dan nilai $t_{\text {tabel }} 1.96$, dengan demikian $t_{\text {hitung }}$ lebih besar dari $t_{\text {tabel }}(2,196>1.96)$ sehingga H0 ditolak (Ha diterima). Hal ini berarti kompensasi berpengaruh signifikan terhadap kinerja melalui kepuasan kerja awak kapal tunda pada PT. Aman Bahari Kuala Tanjung.

Kompensasi kepada karyawan akan memberikan kepuasan kerja tersendiri untuk karyawan, apabila seorang karyawan mendapatkan kompensasi yang pantas atas apa yang sudah dikerjakan pada perusahaan maka karyawan tersebut juga akan mendapatkan kepuasan kerja yang baik sehingga semangat kerja keryawan tersebut akan semakin tinggi dan pada akhirnya kinerja karyawan akan semakin tinggi. Kompensasi adalah semua pendapatan yang berbentuk uang, barang langsung atau tidak langsung yang diterima karyawan sebagai imbalan atas jasa yang diberikan kepada perusahaan (Hasibuan, 2010)

\section{KESIMPULAN}

Berdasarkan hasil penelitian dan pembahasan yang telah dikemukakan sebelumnya maka dapat diambil kesimpulan dari penelitian mengenai Pengaruh Dukungan Organisasi Dan Kompensasi Terhadap Kinerja Awak Kapal Tunda Melalui Kepuasan Kerja Pada PT. Aman Bahari Kuala Tanjung adalah sebagai berikut.

1. Secara langsung dukungan organisasi berpengaruh signifikan terhadap kinerja awak kapal tunda pada PT. Aman Bahari Kuala Tanjung.

2. Secara langsung kompensasi berpengaruh signifikan terhadap kinerja awak kapal tunda pada PT. Aman Bahari Kuala Tanjung.

3. Secara langsung kepuasan kerja berpengaruh signifikan terhadap kinerja awak kapal tunda pada PT. Aman Bahari Kuala Tanjung.

4. Secara langsung dukungan organisasi berpengaruh signifikan terhadap kepuasan kerja awak kapal tunda pada PT. Aman Bahari Kuala Tanjung.

5. Secara langsung kompensasi berpengaruh signifikan terhadap kepuasan kerja awak kapal tunda pada PT. Aman Bahari Kuala Tanjung.

6. Secara tidak langsung dukungan organisasi berpengaruh signifikan terhadap kinerja awak kapal tunda melalui kepuasan kerja pada PT. Aman Bahari Kuala Tanjung.

7. Secara tidak langsung kompensasi berpengaruh signifikan terhadap kinerja awak kapal tunda melalui kepuasan kerja pada PT. Aman Bahari Kuala Tanjung. 


\section{DAFTAR PUSTAKA}

Adhan, M., Jufrizen, J., Prayogi, M. A., \& Siswadi, Y. (2020). Peran Mediasi Komitmen Organisasional pada Pengaruh Kepuasan Kerja terhadap Kinerja Dosen Tetap Universitas Swasta di Kota Medan. Jurnal Samudera Ekonomi Dan Bisnis, 11(1), $1-15$.

Arif, M., Syaifani, P. E., Siswadi, Y., \& Jufrizen, J. (2019). Effect of Compensation and Discipline on Employee Performance. Proceeding of The 3rd International Conference on Accounting, Business \& Economics (UII-ICABE 2019), 263-276.

Danish, R. Q., Ramzan, S., \& Farid, A. (2013). Effect of Perceived Orgarnizational Support and Work Environtment on Organizational Commitment; Mediating Role of Self Monitoring. Advances In Economic and Business, 1(4), 312-317.

Dewi, C., Lie, D., Efendi, E., \& Sherly, S. (2018). Pengaruh Kompensasi dan Motivasi Terhadap Kepuasan Kerja Pada PT. Duta Muda Indonesia Area Pematangsiantar. Maker: Jurnal Manajemen, 4(1), 1-16.

Erdogan, B., \& Enders, J. (2007). Support from The Top: Supervisors' Perceived Organizational Support as a Moderator of Leader-Member Exchange to Satisfaction and Performance Relationship. Journal of Applied Psychology, 92(2), 321-330.

Handoko, H. (2000). Manajemen Personalia. BPFE.

Hasibuan. (2010). Manajemen Sumber Daya Manusia.

Hendro, T. (2018). Pengaruh Kompensasi Dan Kepuasan Kerja Terhadap Kinerja Karyawan Tetap CV. Karya Gemilang. AGORA, 6(1).

Jufrizen, J. (2016). Pengaruh Kompensasi Dan Pengembangan Karir Terhadap Kinerja Karyawan. Jurnal Keskap FISIP, 14(2), 579-592.

Jufrizen, J. (2017). Efek Mediasi Kepuasan Kerja pada Pengaruh Kompensasi Terhadap Kinerja Karyawan. Jurnal Ilmiah Manajemen Dan Bisnis, 17(01), 34-35.

Jufrizen, J. (2018). Peran Motivasi Kerja Dalam Memoderasi Pengaruh Kompensasi Dan Disiplin Kerja Terhadap Kinerja Karyawan. The National Conferences Management and Business (NCMAB) 2018, 405-424.

Jufrizen, J., Lumbanraja, P., Salim, S. R. A., \& Gultom, P. (2017). The Effect of Compensation, Organizational Culture and Islamic Work Ethic Towards the Job Satisfaction and the Impact on the Permanent Lecturers. International Business Management, 11(1), 53-60.

Jufrizen, J., Sari, M., Muslih, M., \& Purnama, N. I. (2021). The Role of Moderation of Organizational Support on Social Capital Effects on Performance of Lecturers. Independent Journal of Management \& Production (IJM\&P), 12(2), 450-469. https://doi.org/10.14807/ijmp.v12i2.1304

Kadir, S., Hariadi, S. S., \& Subejo, S. (2016). Pengaruh Dukungan Organisasi dan Kemampuan Individu Terhadap Kinerja Penyuluh Sosial dan Partisipasi Masyarakat. Sosio Konsepsia: Jurnal Penelitian Dan Pengembangan Kesejahteraan Sosial, 6(1), 1-16.

Khair, H. (2017). Manajemen Kompensasi. Madenatera.

Larasati, S. (2018). Manajemen Sumber Daya Manusia. Deepublish.

Lupiyoadi, R., \& Hamdani. (2011). Manajemen Pemasaran Jasa. Salemba Empat.

Makaluas, C. G., \& Sumampouw, H. j. (2017). Pengaruh Kepuasan Kerja Terhadap Kinerja Karyawan Pada PT. BPR Prisma Dana Manado. Jurnal Administrasi Bisnis (JAB), 5(5), 1-13.

Mangkunegara, A. A. (2014). Evaluasi Kinerja Sumber Daya Manusia. Refika Aditama. Maryati, M. C. (2014). Manajemen Perkantoran Efektif. UPP STIM YKPN. 
Nooralizad, R., Nadeholi, G., \& Parivash, J. (2011). A causal model depicting the influence of spiritual leadership and some organization and individual variables on workplace spirituality. Journal of Advance in Management, 4(5), 90-99.

Pratama, S. A. (2015). Pengaruh Kompensasi Terhadap Kinerja Karyawan (Studi Kasus Pada Karyawan PT. Asuransi Jiwasraya Persero Regional Office Malang). Jurnal Administrasi Bisnis, 25(1), 1-17.

Rahayu, N. M. N., \& Riana, I. G. (2017). Pengaruh Kompenasai Terhadap Kepuasan Kerja dan Keingian Keluar Pada Hotel Amaris Legian. E-Jurnal Manajemen Unud, 6(11), 5804-5833.

Rhoades, L., \& Eisenberg, R. (2008). Perceived Organizational Support: A Review of the Literature. Journal of Applied Psychology, 87(4), 698-714.

Riantoko, R., Sudibya, G. A., \& Sintaasih, D. K. (2017). Pengaruh Dukungan Organisasi Terhadap Motivasi Kerja dan Kinerja Anggota Polsek Kuta Utara. E-Jurnal Udayana, 6(3), 1-15.

Rivai, V. (2014). Manajemen Sumber Daya Manusia Untuk Perusahaan (6th ed.). PT. Raja Grafindo Persada.

Siagian, S. P. (2014). Manajemen dan Evaluasi Kinerja. Bumi Aksara.

Susanto, Y. (2017). Peran Kepemimpinan Dalam Pengelolaan Koperasi. Deepublish.

Sutrisno, E. (2010). Manajemen Sumber Daya Manusia. Erlangga.

Sutrisno, Edy. (2010). Manajemen Sumber Daya Manusia. Penerbit Kencana.

Syahputra, I., \& Jufrizen, J. (2019). Pengaruh Dilkat, Promosi dan Kepuasan Kerja Terhadap Kinerja Pegawai. Manggeio: Jurnal Ilmiah Magister Manajemen, 2(1), 104-116.

Usman, S., Rambe, M. F., \& Jufrizen, J. (2021). Pengaruh Penempatan, Kompensasi Dan Pelatihan Kerja Terhadap Kinerja Pegawai Inspektorat Kabupaten Mandailing Natal. Jurnal Humaniora : Jurnal Ilmu Sosial, Ekonomi Dan Hukum, 5(1), 90-101. https://doi.org/10.30601/humaniora.v5i1.1671

Wibowo, W. (2010). Manajemen Kinerja. Rajawali Pres.

Yulianita. (2017). Pengaruh Kompensasi Terhadap Kepuasan Kerja Karyawan Pada PT. Gemilang Utama Ideal Palembang. Jurnal Adminika, 3(1), 70-71.

Zahra, R. N., \& Hidayat, H. (2017). Pengaruh Kepuasan Kerja dan Disiplin Kerja Terhadap Kinerja Karyawan Bank di Kota Batam. Journal Of Applied Managerial Accounting, 1(2), 1-13. 